\title{
NEJPRVE DVOREC - NAKONEC POZDNĚ RENESANČNÍ DEPENDENCIE
}

\author{
MIROSLAV PLAČEK
}

\begin{abstract}
Abstrakt: Kněžice jsou starobylou obci a kolébkou moravského rozrodu Hrutovců. Badatelé obecně soudili, že jejich sídlo z první poloviny 13. století se nacházelo u kostela. V tomto prostoru se však zformovalo proboštstvi želivských premonstrátů, viceméně fara. Roku 1364 přešly Kněžice na pány ze Starče, za nichž se roku 1407 zmiňuje rezidenční dvi̊r, který Bohuš z Holoubka přeměnil na tvrz a 1417 prodal Janu Drhovi z Dolan. Zanikla za husitských válek a pobliž ní po roku 1600 vystavěl Zdeněk Brtnický z Valdštejna jako dependencii k zámku v Brtnici blokové patrové letní sídlo se vstupni věži a rizality v průčeli. Nárožím bylo napojeno na úředni dům a dvorem vymezené nádvoři. Zachovány jsou klenby prízemí a některé prvky upravené v třetině 18 . století za Collaltů, kteři panství ziskali po Bílé hoře. Utilitární úpravy naštěstí nepostihly podstatu a nedávno proběhla kvalitní revitalizace objektu.
\end{abstract}

Klíčová slova: páni z Kněžic-rezidenčni dvur-tvrz-zámek-proboštství.

\section{From a Homestead to a Late Renaissance Dependency}

Abstract: Kněžice is an old village and the cradle of the Moravian dynasty of the Hrutovecs. Researchers generally believe that the seat of the dynasty dating from the first half of the 13th century was situated by the local church. However, this site was occupied by the provostry of the Želiv Premonstratensians, more or less a parsonage. In 1364 Kněžice passed to the lords of Stareč, under whom a residential homestead is mentioned in 1407, converted into a manor by Bohuš of Holoubek who sold it to Jan Drha of Dolany in 1417. The manor ceased to exist during the Hussite wars. Zdeněk Brtnický of Valdštejn built nearby a two-storey summer residence with an entrance tower and bay windows in the frontage, a dependency of the chateau in Brtnice, after 1600. Its corner adjoined an administrative house and a courtyard. The vaults on the ground floor have survived, along with some elements modified in the first third of the 18th century, under the Collaltos who acquired the demesne after the Battle of White Mountain. Fortunately, these utilitarian modifications did not affect the core of the building, which has recently undergone high-quality refurbishment.

Key words: lords of Kněžice - residential homestead - manor-chateau-provostry.

Jméno Kněžic se v pramenech objevilo poprvé v roce 1222, kdy na jedné z posledních listin markraběte Vladislava Jindřicha tvoří predikát svědčící osoby Hericha z Kněžic. Ladislav Hosák $(1938,154)$ s jistou pravděpodobností soudil na totožnost s Dětřichem z Kněžic, který se objevil ve stejném roce spolu se synem Hrutem, ale i sám (CDB II, č. 222; č. 232; č. 234). Byli to př́íslušníci větve domácího šlechtického rozrodu s erbem, tzv. poloutrojčáŕí, která se podle oblíbeného jména nazývala Hrutovci (Sedláček 1893, 292; Pilnáček 1930, 270; Hosák 1938, 154). Po Kněžicích se psali až po jejich nabytí, nejspíše formou výsluhy od panovníka, na jehož fundátorskou úlohu ukazuje tvar místního jména. Vysazeny zřejmě byly, když (moravští) vládci ještě měli titul knížete, i když se L. Hosák a R. Šrámek $(1970,402)$ více klonili k odvození jména od lidí knězových. Argument, že ves dílem patřila želivskému konventu pod správou jejich kněze, je však planý, nebot' jeho místní proboštství vzniklo zhruba o čtvrt století později a nic v Kněžicích nevlastnil.

Obdarování Hrutovců bylo asi odměnou za působení členů rodu v provinciálních úřadech Znojemska a především Bítovska. Oprávněnost pojmenování rodu lze opřít o starší pramenné zmínky. Pomineme-li Hruta (z Bukoviny) z dolnokounického falza, které se hlásí k roku 1173, a zavrhneme Yroda a Iroba z pravé písemnosti z roku 1180 (CDB I, č. 400; č. 292), v roce 1213 svědčí Dětřich, syn Hrutův. Hrut starší tedy existoval, což dokládá i jméno Zdislav Hrutovič z roku 1207 (CDB II, č. 109; č. 53). O tom, že Zdislav byl bratrem Dětřicha a doplňoval je třetí Mutina, vypovídá věrohodné falzum stvrzení donací zábrdovické kanonii z první třetiny 13. věku. Na Kněžicích zůstal a v úřadech ve Znojmě a na Bítově v letech 1232-1259 působil Dětřichův syn Hrut a po něm takřka obligátně až do roku 1289 syn Dětřich (CDB II, č. 364; č. 110; Měřínský-Plaček 1989, 233, 235-236; CDB V/2, č. 872; CDM V, Suppl. č. 90). Dětřich byl posledním známým Hrutovcem na Kněžicích, ale další byli usazeni v Branišovicích a následně v Boleradicích, resp. v Suchohrdlech. Nemluvě o rozkošatělých a bohatých větvích pánů 


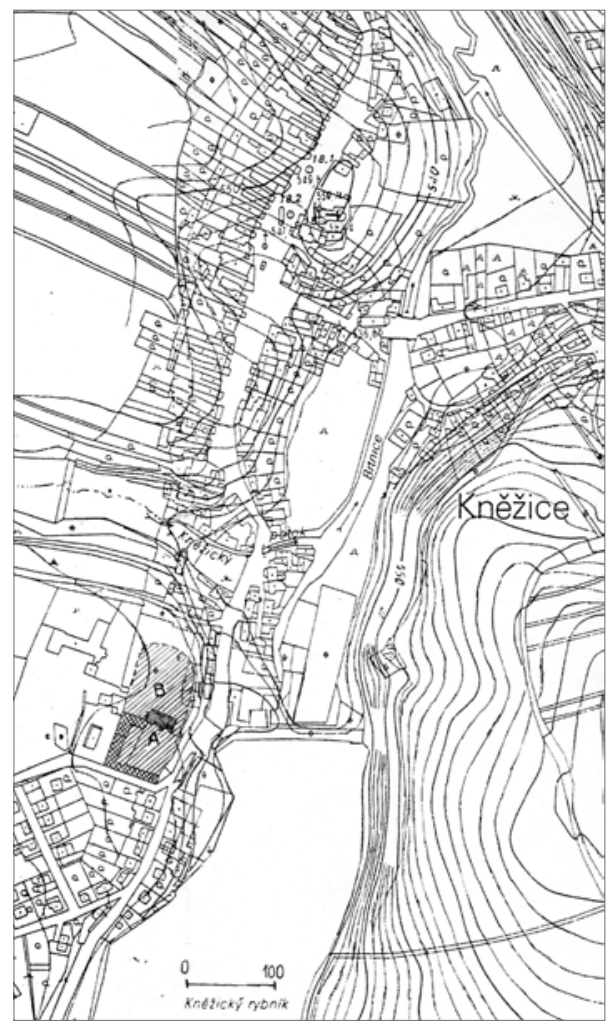

Obr. 1. Kněžice na základní mapě 1 : 5000 . Kostel s farou (proboštstvím) stojí na pahorku v severní části obce, tmavě položená dependencie s mřížkovaným dvorem (A) se nachází nad rybníkem, panský okrsek, v němž stála tvrz, zahrnuje i šrafované plochy $(B)$.

Abb. 1. Knieschitz auf der Grundkarte 1 : 5000 . Die Kirche mit Pfarrei (Probstei) steht auf dem Hügel im nördlichen Teil der Gemeinde, die dunkel abgesetzte Dependance mit gerastertem Hofe (A) befindet sich oberhalb des Fischteichs, das Gebiet der Gutsherrschaft, in dem die Feste stand, umfasst auch die schraffierten Flächen (B). z Holštejna a ze Sovince na střední a severní Moravě (Plaček 2015, 58; Pilnáček 1930, 270; Papajík 2005; 2007).

Tyto Hrutovce však nelze spojovat se zakladatelským rodem fundátora hradu Rokštejna, ač jej založil právě Hrut (Rutho), který ho po sobě nazval a v roce 1289 se po něm psal. Podle erbu se znamením leknínového lupenu beze stopky byl nepochybně jiného původu, k čemuž dospěl i Zdeněk Měřínský (2007, 15-16). Spolu s bratry Bernardem, Zdislavem a Vršem byl Hrut členem vladyckého rodu s ekonomickým a predikátním centrem ve Stř́ižově, proto je trefnější označení Stř́ížovci. Podle křestních jmen Hrut a Zdislav pocházela jejich matka zřejmě z Hrutovců, ale byli též spřízněni s rodem Vršovců (z Říše). Území kolem hradu Rokštejna a severně od řičcky drželi Stř́ižovci a po jeho ztrátě ve prospěch panovníka potomci zakladatelské generace občas působili jako jeho správci, možná i jako zástavníci (k rodu Vohryzek 2011; 2012).

Po odbočce nazpět do Kněžic - kde lze důvodně předpokládat hrutovské sídlo, v době do poloviny 13. století však nanejvýš jen ve formě rezidenčního dvora - feudálního dvorce. Otázku počátků důstojnější tvrze více méně řeší písemné zprávy ze začátku 15 . století. Po zpracování stavebně historického průzkumu zámku a zjištění vazeb na okolí je $\mathrm{k}$ dispozici i náznak jejího situování. Je téměř jisté, že držitelé po celé 13. a 14. století v Kněžicích lepší sídlo neměli a jedním z důvodů je skutečnost, že již za Hruta II. někdy v polovině 13. věku došlo při kostele sv. Jakuba Většího ke vzniku proboštství, jež se připomíná roku 1257 (CDB V/1, č. 108). Tehdy Hrutova

sestra Adelheida tuto čerstvou filiaci želivské premonstrátské kanonie majetkově obdařila. Další majetkovou injekci dodal Markvart z Říše v roce 1278 a o rok později probošt Vojslav zboží obhájil (CDB V/2, č. 872; CDM VII, Suppl. č. 142). Patronáty v Opatově a Moravanech darované roku 1289 Dětřichem z Kněžic ale proboštství nedokázalo udržet, leč zůstaly mu drobné majetky na Znojemsku a Moravskokrumlovsku (CDM VII, Suppl. č. 147; Charouz 1984, 314-317).

Jelikož se nedochovaly žádné stavební pozůstatky proboštství, ani místní tradice situování jeho budov, lze dovodit, že šlo zřejmě o faru, jejíž správce nesl titul probošta. Také proto je obtížně akceptovatelná myšlenka o kolonizaci okolí a hlavně vysazení Kněžic želivským klášterem. Navíc sousední vesnice jižním směrem nese jméno Hrutov. Existence této instituce na říčce Brtnici tedy počíná v době, kdy Kněžice byly nějaký čas v rukách Hrutovců a od vzdáleného Želiva je oddělovalo nejen území Ranožírovců na Jihlávce, Kostelecko a několik hřebenů Vysočiny (Hosák 1952, 149; Richter 1953, 20, 23, 24; Měŕínský 1988, 24, 25). Proto i jméno nedalekého Opatova se může vztahovat k jiné a bližší církevní instituci. Kněžický kostel sv. Jakuba Většího má pozdně románské jádro (lod' z doby okolo roku 1240) a nepochybně ho založili Hrutovci, snad za asistence želivského konventu (Kudělka 1977-1978, 41). Proto a díky př́ízni majitelů 


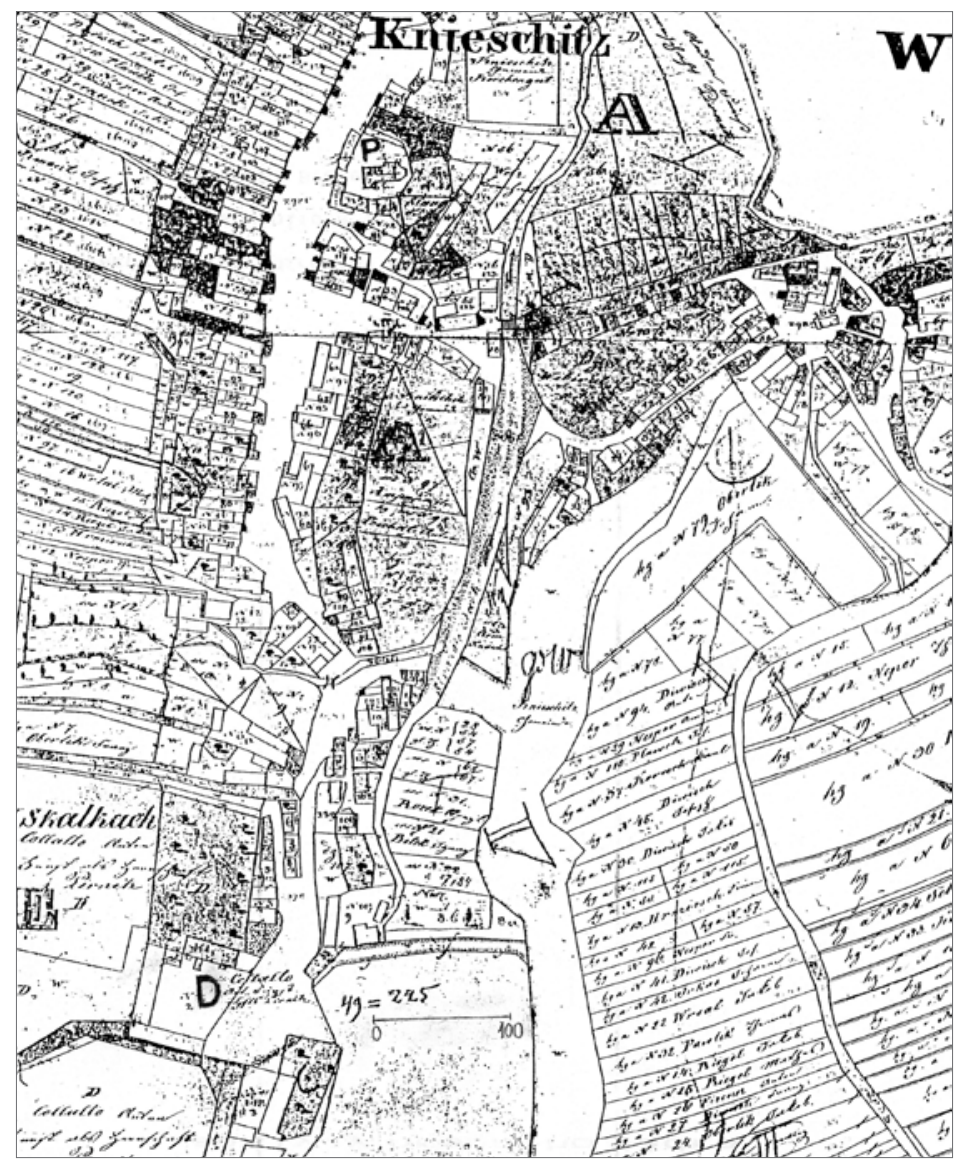

Obr. 2. Otisk stabilního katastru Kněžic z roku 1835. P - sakrální okrsek s farním kostelem sv. Jakuba Většího, D - dominikální okrsek se zámečkem a dvorem, park severně od něho. Abb. 2. Abdruck des Stabilen Katasters von Knieschitz aus dem Jahr 1835. P - Sakralbereich und Pfarrkirche St. Jakob der Ältere, D - Dominikalbezirk mit kleinem Schloss und Hof, nördlich davon der Park.

došlo k postoupení patronátu a několika okolních vsí Želivu, což nepochybně zkomplikovalo výstavbu kvalitního sídla.

Sídlo nestálo na výšině bezprostředně u kostela, kde lze očekávat faru - proboštství -, a někteří autoři již dřive situovali tvrz do prostoru zámku, kde také byl panský dvůr (Večeřa-Ondráček-Pejchal 1994, 65; Samek 1999, 145). Skutečně, na výběžku ve středu obce u kostela nebyl pro větší panský hospodářský nebo rezidenční dvůr dostatek místa a zaoblená plochá terasa nad komunikací vedoucí údolím Brtnice a Panským (Kněžickým) rybníkem splňuje také požadavky na situování tvrze.

V každém prrípadě byl Dětřich z Kněžic zmíněný v roce 1289, a nepochybně vlastnící i Opatov, posledním známým př́íslušníkem mateřské větve rodu. Do roku 1351, kdy se po vsi sice píše Hrut z Kněžic, chybějí relace o majitelích Kněžic (ZDB II, č. 53). Ovšem podle erbu zavinuté střely na pečeti pochází tato osoba ze zcela jiného rodu $-z$ Benešoviců. Kromě erbovního znamení dokládá jeho původ jméno bratra s častým rodovým jménem Vok (Pilnáček 1930, 200) a Kněžice asi nabyl jejich otec, a to nejspiše věnem ženy z rodu Hrutovců. Ale dlouho jim zboží 


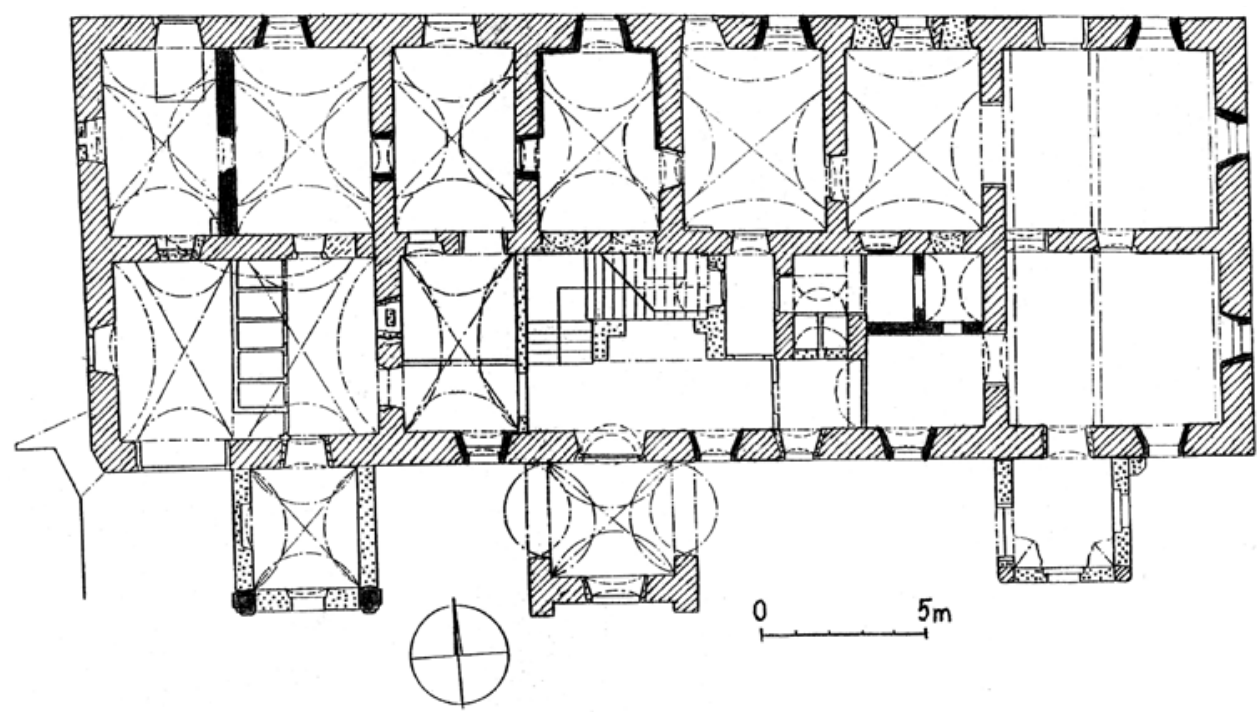

Obr. 3. Zámeček, analýza půdorysu přízemí. Šrafovaně - pozdně renesanční zdivo, černě je položeno zdivo barokní, tečkovaně zdivo z 19. století, bílé je zdivo 20. století. Vypracoval autor; podklad Státní projektový ústav obchodu Brno, upravené zaměření stávajícího stavu, únor 1989.

Abb. 3. Kleines Schloss, Grundrissanalyse des Erdgeschosses. Schraffiert - spätrenaissancezeitliches Mauerwerk, schwarz hervorgehoben ist das Barockmauerwerk, punktiert das Mauerwerk aus dem 19. Jahrhundert, weiß das Mauerwerk des 20. Jahrhunderts. Ausgearbeitet vom Verfasser; Vorlage Staatliches Planungsinstitut Brno, bearbeitete Vermessung des gegenwärtigen Zustandes, Februar 1989.

nezůstalo. Hrut s bratry Dobešem, Vokem a Herešem v roce 1364 prodali Kněžice, Rychlov, Petrovice, Mosty a díl Strážova Bohušovi ze Starče a Holoubka (ZDB IV, č. 151). Deskový zápis hovoří o vsích a jejich př́íslušenství, takže nelze s jistotou určit, jaký ráz sídlo v Kněžicích mělo.

Po smrti Bohuše získal kněžické zboží jeden z jeho tří synů - Mikeš Rulant z Holoubka, který roku 1376 na něm pojistil věno ženy Anežky. V zápise zmínil stavbu dvora (curie). Nedržel panství dlouho a o deset let později je zčásti intabuloval sestře Evě a bratru Bohušovi z Holoubka. V roce 1390 Mikuláš Rulant převedl celé Kněžice přes prostředníka Bohuše z Vanče na bratra Bohuše z Holoubka. Osudy pánů z Holoubka relativně čerstvě pojednal Stanislav Vohryzek (2013). Bohuš při zápisu věna své ženě Elišce v roce 1406 zmiňuje okolí nynějšího zámku - hovoří o dvoru, rybníku nad Kněžicemi a mlýnu při něm (ZDB VI, č. 227; VII, č. 500; ZDB VII, č. 742, 743; VIII, č. 549). V Kněžicích patrně sídlil, nebot' se po nich ve stejném roce psal a navíc v roce 1407 zmínil dvůr, ve kterém bydlí. Znovu se sídelní dvůr připomíná roku 1417, ale téhož roku Bohuš intabuloval zboží s tvrzi Janovi Drhovi z Dolan z rodu Ranožírovců (LC II, 27; ZDB IX, č. 66; XI, č. 354; 384; Pilnáček 1930, 162). Je jasné, že šlo o jeden objekt, který byl obvyklým způsobem opevněn, takže kvůli ceně mohl být při prodeji označen jako tvrz.

O pravděpodobném umístění objektu v dominikálním okrsku svědčí okamžitý Drhủv zápis manželce Anně, v němž ho uvedl jako alodiální dvůr u Kněžic. Dále zmínil louku k němu se táhnoucí a mlýn s rybníkem pod dvorem ležící. Současně vstoupil ve spolek s Janem ml. z Hradce, čímž si asi v neklidné době zajistil podporu mocného feudála (ZDB XI, č. 386; č. 387). Zdá se tedy, že v místě zrušeného dvora a pozdějšího zámku vznikl nejpozději na přelomu 14. a 15. století z hospodářského dvora sídelní dvorec podobou blízký jednoduše opevněné tvrzi.

Osudy tvrze dále nejsou jasné, zvláště když následovalo složité období husitských válek a následných mocenských peripetií. Při převodu kněžického statku z Janova syna Václava Drhy z Dolan na Václava z Maříže v roce 1464 již není tvrz jmenována a neuvádí se ani nadále. Zdá 


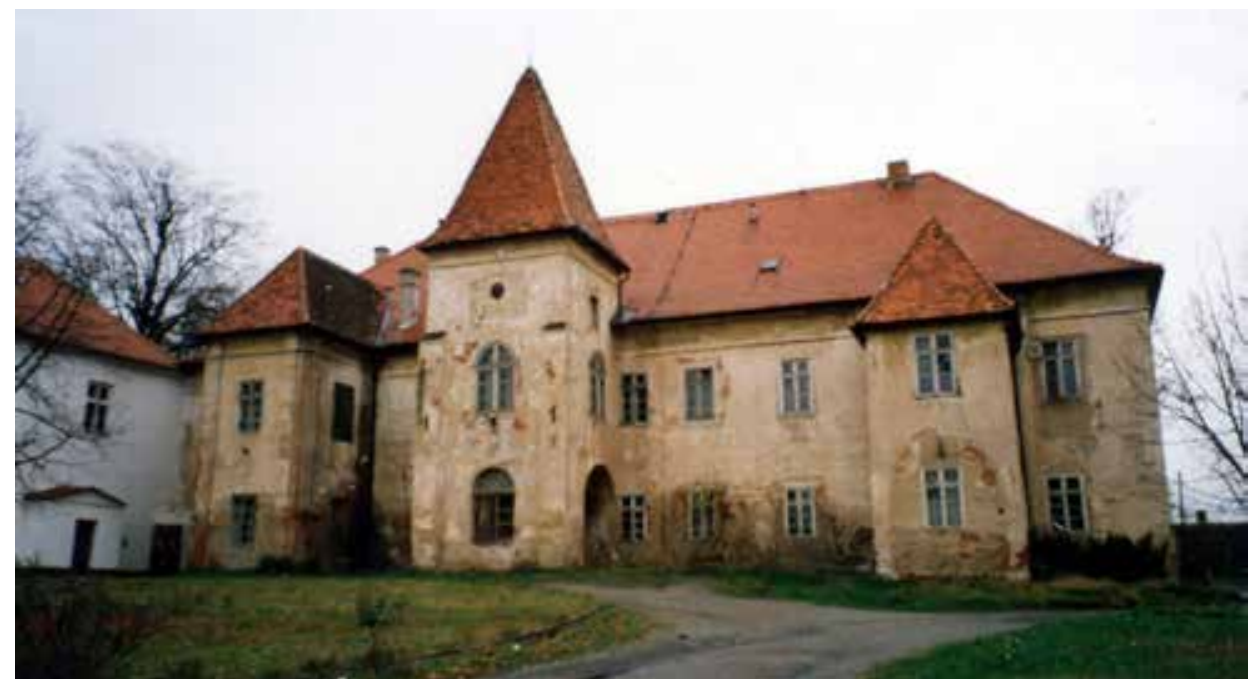

Obr. 4. Zámek, celkový pohled od jihu, 1997.

Abb. 4. Schloss, Gesamtansicht von Süden, 1997.

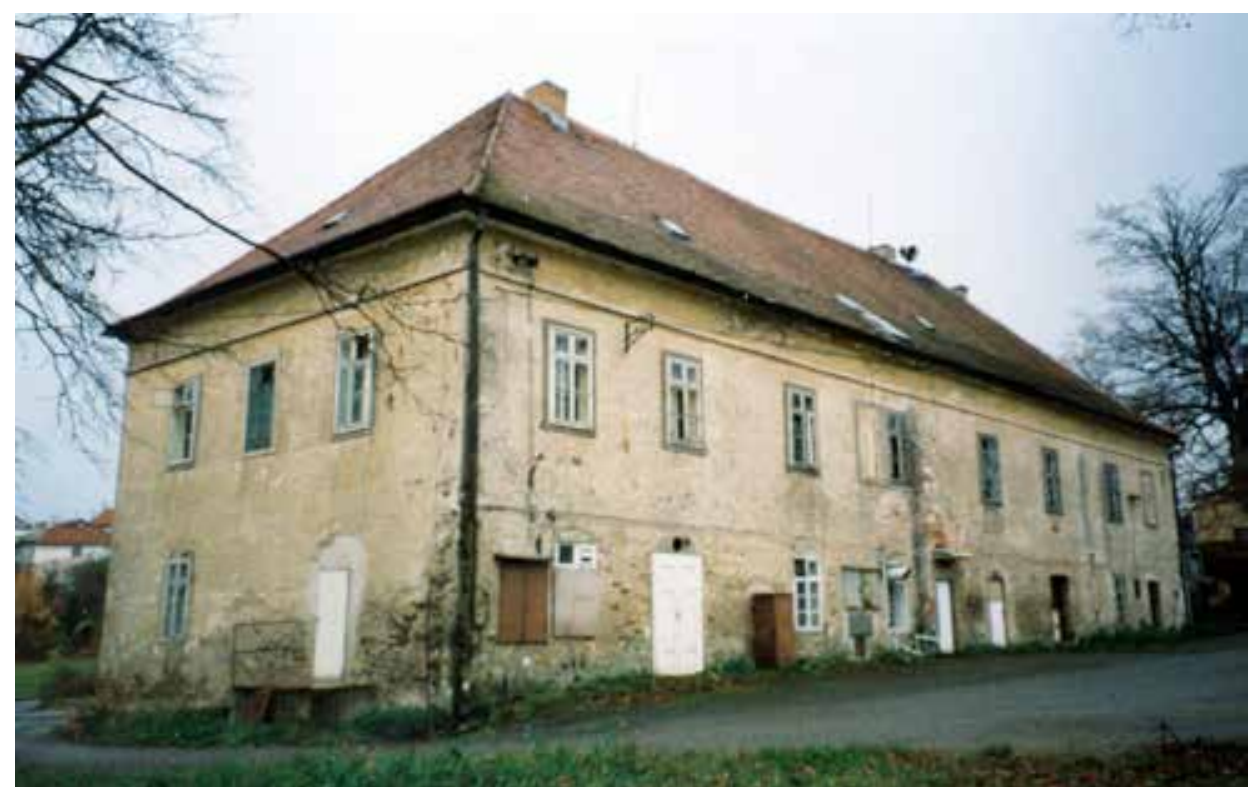

Obr. 5. Zámek, celkový pohled od severovýchodu, 1997.

Abb. 5. Schloss, Gesamtansicht von Nordosten, 1997.

se, že Jan Drha z Dolan a Kněžic, jenž ještě krátce před smrtí v roce 1446 přikoupil rudolecké panství, jehož součástí byla tvrz, využíval nově získané sídlo. Jednoduchou kněžickou tvrz, možná i poškozenou, nechal zpustnout on, nebo jeho syn, který byl knězem (ZDB XIII, č. 12; XII, č. 457). 
Václav z Maříže si patrně ponechal Rudolec a Kněžice roku 1480 odprodal Hynkovi Brtnickému z Valdštejna. Současně se Valdštejnové zmocnili i tří vsí příslušných ke kněžickému patronátu (Víska, Hrutov a Brodce), za což je roku 1481 želivský konvent pohnal k soudu (ZDB XV, č. 25; LC V, č. 285). Spory se táhly až do roku 1547, kdy želivský opat Ondřej „daroval“ tyto vsi Zdeňkovi z Valdštejna jako kmotrovský dar (Pátek 1901, 178; ZDB XXVI, č. 220). V důsledku toho proboštství zaniklo. Burian z Valdštejna zapsal roku 1508 věno své ženě Kateřině z Ludanic na Kněžicích, přičemž v tomto zápisu i v dalších písemnostech 16. století chybí jakékoliv zmínky o tvrzi. Dokonce roku 1590, v zápisu Zdeňka Brtnického z Valdštejna manželce Kateřině Zajímačce z Kunštátu a Jevišovic, se nehovoří o kněžickém dvoru, který nefiguruje ani v urbáŕi panství z roku 1533-1538, kde je ale uveden dvořák (ZDB XVIII, č. 20; XXX, č. 48; MZA Brno, G 10 Nová sbírka rukopisů, č. 638). Dvůr Její Milosti však uvádí urbář z roku 1570, chybí však dvořák a ke dvoru patří rybník a mlýn, tedy opět stejný dominikální okrsek, který dočasně držel onen dvořák. Až ve třetím urbáři z roku 1585 se o dvoru nehovoří. Dávky z hospodaření ve vlastní režii se v něm zřejmě nesledovaly (MZA Brno, G 168 Rod. archiv Collalto I, č. 2562, č. 2561).

Po smrti Zdeňka z Valdštejna († po 1514) jako vlastník následoval jeho bratr Burian († 1544), pak Burianův syn Zdeněk, který zemřel roku 1561. Panství zdědil jeho zmíněný syn Hynek, po jehož smrti († 1596) o ně pečovala manželka Kateřina z Kunštátu. Zemřela v roce 1600 a zboží převzal Hynkův synovec Zdeněk, syn Jindřicha Brtnického z Valdštejna a na Sádku (Hosák 1938a, 40, 41; Zaoralová 1988, 107, 111, 120). Světaznalý Zdeněk studoval ve Štrasburku, cestoval po Evropě a oženil se s Magdalenou z Thurnu. Tři roky po její předčasné smrti († 1614) vstoupil do manželství s Kateřinou Křineckou z Ronova. Kvůli své konfesi a také díky oběma ženám se přiklonil ke stavovskému odboji a stal se jedním z 29 moravských direktorů. Proto jej roku 1621 vítězný císař nechal zatknout; 24. června 1923 ve špilberském vězení zemřel. Konfiskované panství bylo již 2. dubna 1623 předáno Rombaldovi de Collalto et San Salvatore (Zaoralová 1988, 123, 124). Pro poznání stavu panství je důležitý konfiskační odhad z roku 1622 (MZA Brno, G 2 Nová sbírka, č. 404/4; srov. Hrubý 1927). V Kněžicích je totiž uvedena tvrz, rozuměj zámeček, což svědčí o její stavbě mezi lety 1590 a 1619.

Éra italského rodu Collaltů započala v období hrůz třicetileté války, které přirozeně poznamenaly i brtnické panství. V této době se Rombald ideologicky orientovanou stavební aktivitou také pokouší o rekatolizaci poddaných. Roku 1628 započal se stavbou kláštera pavlánů, ale nezapomněl ani na zámek. Bylo to však jen krátké vzepětí, nebot' v roce 1630 Rombald umřel v cizině (Balcárek 1988, 139-141). Poničení brtnického okolí souvisí s pobytem švédské posádky v Jihlavě po bitvě u Jankova v roce 1645. Vojensky se zmocnili zámku v Brtnici a hradu Sádku, které vydrancovali a nepochybně navštívili i neopevněný zámeček v Kněžicích. Území okolo Kněžic od svého plukovníka v roce 1624 obdržel Rombaldův důstojník František de Couriers (Balcárek 1988, 143; Knoz 2006, 681).

Po nějakém čase se panství ujal Rombaldův syn Klaudius, který měl v době otcovy smrti jen čtyři roky, a v letech 1650-1655 nejdříve obnovil brtnický zámek. Zemřel poměrně mlád v roce 1661 a panství po něm převzal bratr Antonín František, který věnoval pozornost hlavně Brtnici. Jeho následník Leopold Adolf dědil roku 1698, ale nežil dlouho, nebot' v roce 1707 padl v souboji a rok nato se zboží ujal člen italské větve rodu pocházející od Rombaldova bratra Antonín Rombald. Projevil se jako mecenáš a milovník umění a také i pilný stavebník, za něhož také vznikl cyklus obrazů K. F. Teppera zachycující návštěvy panovníků v Brtnici (Zaoralová 1988, 151-153, 164, 170; Večeřa-Ondráček-Pejchal 1994, 51). V jeho době († 1740) nepochybně nastaly příznivé podmínky pro úpravy pozdně renesančního kněžického zámku.

Nepř́liš výrazně se projevili další dva držitelé Kněžic - hrabě Tomáš Vinciguerra, jenž se soustředil na obnovu Brtnice, která roku 1760 vyhořela, a jeho syn Jan, který však žil jen krátce († 1772). Také období Antonína Oktaviána (1772-1793) bylo pro Kněžice a jejich zámek málo významné. Až za jeho nástupce Eduarda se situace změnila. Eduard jednak žil dlouho († 1833), a to v pohnuté době napoleonských válek, a roku 1822 byl povýšen do knížecího stavu. Při kopání základů kulturního domu v roce 1974 byl nalezen hrob 15 osob z počátku 19. století, 
což navozuje možnost využití kněžického zámku během válek jako lazaretu (Večeřa-Ondráček-Pejchal 1994, 22, 117). Následky válek patrně Eduard napravil empirovou úpravou zámku, kterou lze na stavbě slohově sledovat.

Po Eduardovi se majitelé stř́idali a za Emanuela Josefa Antonína proběhl převrat a po vzniku Československé republiky také pozemková reforma. Do zbytkového statku Oktaviána Collalta byl rovněž zahrnut kněžický zámek, který patrně v třetině 20. století prošel posledními kvalitními úpravami. Není vyloučeno, že jejich iniciátorem byl hrabě Eduard Mensdorf-Pouilly, manžel Oktaviánovy sestry, který na zámku od roku 1927 žil a na pohodlí mu záleželo (VečeřaOndráček-Pejchal 1994, 52, 54, 148). Konec druhé světové války byl spojen se zajetím příslušníků gestapa, kteří zámek využívali, přinesl vyplenění zámeckého mobiliáře a především odchod šlechtických majitelů a postátnění jejich majetku včetně kněžického zámečku. Ten nebyl do roku 1948 nijak využit, pak krátce sloužil jako odloučená měšt’anská škola. Po založení JZD v něm ukládali náhradní díly a také obilí a dokonce došlo k dílčím úpravám na dílny.

Roku 1958 vichřice těžce poškodila zbytky zámeckého parku, ale nenašla se ochota a prostředky k jeho obnově. Naopak v roce 1964 v něm zřídili parket pro letní lidové veselice a počátkem 80. let pokáceli staré lípy před zámkem. Od roku 1960 zámek opět upravili, tentokrát na kanceláře zemědělského družstva, které ho roku 1968 získalo do vlastnictví. V přízemí pak zřídilo závodní kuchyni a jídelnu a brzy zámek navíc vybavilo ústředním topením. V bývalém parku, namísto parketu, v letech 1974-1980 vyrostl kulturní dům a předtím v 60. letech zbořili také větší část dvora, zbytek byl upraven na garáže autobusů (Večeřa-Ondráček-Pejchal 1994, 108, 105, 107). Po roce 1989 došlo ke změně využití vedlejší budovy, kterou rekonstruovali na zdravotní středisko, naopak vlastní zámek opustilo transformované družstvo, a proto utilitárně upravený objekt pomalu stavebně chátral. Devastaci konečně po roce 2001 zastavilo obecní zastupitelstvo a úsilí o jeho zásadní revitalizaci završila poměrně kvalitní rekonstrukce na obecní úřad s dílčím muzeálním využitím.

Starobylá obec Kněžice se v severojižním směru táhne po protáhlé západní terase podél výrazného údolí, kterým protéká horní tok říčky Brtnice zvané místně Strážov. Údolí zpovzdálí lemují dva hřbety dosahující nadmořskou výšku $650 \mathrm{~m}$. Vzhledem k tomu, že kostel je ve výšce $550 \mathrm{~m}$ a zámek $548 \mathrm{~m}$ n. m., činí převýšení v obou směrech ca $100 \mathrm{~m}$. Kostel stojí v centru obce na výběžku terasy nad brodem (posléze mostem) přes Brtnici. Původní návesní silnicovka končila u potoka, levobřežního prŕítoku Brtnice.

Od potoka také k jihu stoupá bok rozměrné svahové plošiny, která vybíhá východním směrem nad řičcku a nese zámek s příslušenstvím (park, dvůr). Východní úpatí zámecké plošiny lemuje rybník, u jehož hráze, asi na místě staršího, stojí tzv. Panský mlýn. Právě vazba na dvůr a okolní účelové pozemky je důležitá, nebot' ve složitém organismu aglomerace tří vsí (vedle Kněžic ještě Víska a Brodce) a sakrálního okrsku tvoří okrsek dominikální. Od silnice k zámku vede krátká cesta, která ústí na upravenou plochu bývalého panského hospodářského dvora. Budova zámku byla do jeho mírně lichoběžníkového rozvrhu zakomponována, a to úskokem do jeho severní strany. Nárožím tanguje patrovou budovu, k níž se na západě do pravého úhlu pojí krátké západní přízemní křrídlo, jehož větší díl byl po roce 1950 demolován. Stejný osud postihl celé jižní přízemní kř́ídlo dvora. V době existence tvořil dvůr jakousi skromnou obdobu čestného dvora, do něhož se dříve vstupovalo od východu pilírovou branou vsazenou do kovaného plotu na zděné podezdívce.

Severně od zámku se ještě po polovině 20. století dochovaly devastované relikty parku, který zachytila skica stabilního katastru. Na jeho okraji, při východní hraně terasy figuruje na skice řadová zástavba drobných domků patřících patrně zámeckému personálu. Stavba kulturního domu do roku 1980 a návazné planýrování plochy parku zlikvidovaly jeho poslední zbytky, a to prakticky bez možnosti obnovy (Večeřa-Ondráček-Pejchal 1994, 1-7). Pikantní je skutečnost, že literatura se zmiňuje o př́rodním parku ještě v roce 1981, ač ten již tehdy nějakou dobu neexistoval (Hosák-Zemek 1981, 44). Prostranství dvora je částečně upraveno a pozemky jižního křídla byly přiděleny pro individuální výstavbu rodinných domků. 


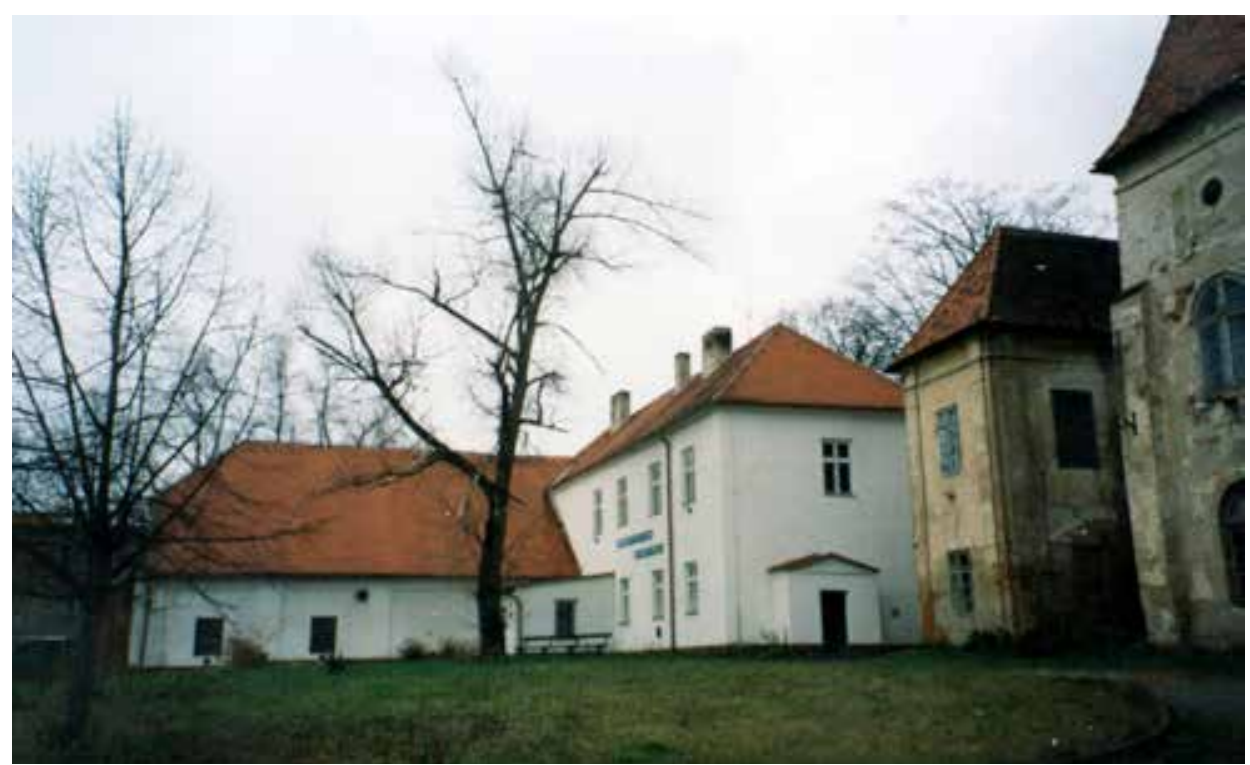

Obr. 6. Západní část zámku (vpravo) a upravený relikt hospodářského dvora, 1997.

Abb. 6. Westlicher Teil des Schlosses (rechts) und hergerichtetes Relikt des Wirtschaftshofes, 1997.

Kněžický zámeček tvoří bloková patrová budova obdélného půdorysu se vstupní věží poněkud mimo osu jižního průčelí a se dvěma hlubokými rizality při jeho koncích. Zastřešen je valbovou střechou. Věž krytá stanovou střechou je v přízemí otevřená do stran obloukovými pasy a zámek převyšuje o výšku podstřeší. Boční rizality jsou nestejně vysoké a byly v přízemí původně otevřené do všech stran. Jsou nižší než věž vstupní a jejich valbové stříšky vybíhají ze střechy hlavní budovy zámku. Dispozičně tvoří př́izemí důsledný podélný dvojtrakt, severní je příčně předělen poměrně pravidelně, jižní obsahoval dva větší prostory na koncích a široký prostor vstupního vestibulu se schodištěm měl po stranách ještě dva prŕíné trakty. Předělený východní sousedí s pozůstatky zdí patrně staršího (renesančního) schodiště.

Dispozice patra je poněkud odlišná od př́izemí a původní se z rozvrhu dá vypreparovat. Podélný dvojtrakt zde navazoval na př́ičný východní sálový prostor, který byl před čerstvou rekonstrukcí ve druhé polovině 20. století předělen na několik místností. Do sálu se původně segmentovým pasem otvíral interiér východního rizalitu. Členění severního traktu v baroku pozměnilo zbourání západní př́íčky, takže vznikl sál, zatímco mezilehlý prostor mezi sály se dělil na tři místnosti. Rovněž jižní trakt měl tři prostory a navíc velký se schodištěm uprostřed. Západní prostor v 19. století rozdělili na dva, do východního v baroku vložili těleso kouřového sběrače $z$ topeništ', rozuměj odstraněných kachlových kamen. Trojramenné schodiště vede z př́izemního vestibulu do horní schodišt'ové haly, odkud také vycházelo zavřené jednoramenné schodiště na půdu. Půdní polopatro vstupní věže je př́stupné dveřmi s barokním kováním. V místech zazděných okének prochází zdivem hřídel ruček bývalých hodin, stroj bohužel chybí.

Svislé konstrukce zámku jsou zděné, jeho bloková část a vstupní věž jsou provedeny převážně $\mathrm{z}$ kamenného zdiva směrem vzhůru víc a víc smíšeného $\mathrm{s}$ cihlami. Kámen převažuje ve zdivu do úrovně pravoúhlé římsy pod římsou korunní, zdi v př́izemí mají sílu $90-100 \mathrm{~cm}$, v patře přibližně $75 \mathrm{~cm}$, vnitřní zdi a prríčky se odlišují dimenzí a materiálem hlavně podle doby původu. Nároží zámku armují pečlivě vybírané, ale neupravované velké kameny. Vysprávky a zazdívky ve zdech a špalety pozdějších otvorů jsou výhradně cihelné. Stejné jsou původní pilíře 




Obr. 7. Jižní průčelí vstupní věže s tesaným erbem, vpravo stopy rýsované rustiky, 1997.

Abb. 7. Südfassade des Eingangsturms mit Wappen, rechts Spuren der sich abzeichnenden Rustika, 1997. pasů, pod nimiž se navenek otvírala prrízemí obou bočních rizalitů. U východního spočívají pilířky na patečních kamenných přitesaných kvádrech a z cihel jsou i zazdívky otvorů pod pasy a mezi pilírí.

Co se týká vodorovných konstrukcí, př́izemí je $\mathrm{v}$ severním podélném traktu a v západní části jižního traktu zaklenuto a klenby mají i podvěží vstupní věže a přízemí západní rizality. Sotva zastoupeny jsou dvě krátké valené klenby, jedna z neomítnutých cihel malého formátu je pokrytá sazemi, nebot' byla součástí zmíněného kouřového sběrače $\mathrm{z}$ kamen. $Z$ ostatních kleneb je polovina (pět) ploše křížových, druhá se blíží valeným se styčnými výsečemi. Všechny klenby zvýrazňují jejich vytažené hrany, což ukazuje na vznik v období doznívající renesance. Pouze barokní křížovou klenbu v přízemí západního rizalitu charakterizuje historizující podseknutí patek. Trámové stropy měla východní část přízemí tam do rekonstrukce byly viditelné průvlaky -, dále ploché stropy kryly přilehlý prostor rizalitu a vstupní novodobě upravenou halu se schodištěm. Výhradně plochostropé patro mělo nepochybně trámové stropy s omítnutým podhledem a některé vyměnili při památkové obnově. Č́st hodnotných stropů patra lemovaly fabiony vycházející z profilovaných říms a pokrývaly je štukové rámy a zrcadla.

Krovy jsou trámové, zadlabávané a spojované dřevěnými čepy a využívají hambalkový systém s námětky. V plných vazbách (každá třetí) je opatřen ztužujícím hambalkovým rámem s páskami a dolním věšadlem dosedajícím na vazný trám. Skromněji, ale také s námětky je proveden krov valbových střech bočních věžic. Krokve krovů nesly latě, na něž byla po roce 1968 položena pálená bobrovka. Nejpozoruhodnější je samostatný krov stanové střechy vstupní věže (rovněž s námětky), nese ho stř̌ední čtveřice stojek spočívající na vodorovném rámu a pochází nejméně z období baroka. Podlahu půdy do poslední památkové rekonstrukce pokrývaly čtvercové pálené půdovky.

Poměrně prostou architekturu stavby dokládají stroze pojednaná průčelí, s výjimkou jižního. Horizontálně jsou členěna jen širokým kladím a v omítce profilovanou hlavní ŕímsou, severní fasádu obohatila kordonová římsa. Západní rizalit obíhá také zalamované kladí, jehož římsa i architráv jsou profilovány, a vlysem prostupují pilastry. Před obnovou byly na těžce narušených průčelích zřetelně vidět pozůstatky jednovrstvé omítky se světle rýsovaným kvádrováním zřejmě pozdně renesančního původu. Sahá až po dolní římsičku kladí a je patrné i na věži a na východní věžici. Západní mladší rizalit je přirozeně postrádá. Kamenická výprava představuje z kamene tesané články, hlavně ostění oken prvního patra, především v severní fasádě. Jedná se o všechna, i zaslepená okna. Zachovaná ostění jsou prosté, neprofilované rámy lemované jednoduchou lištou, bez plastických omítkových šambrán a nadokenních říms. Nejkvalitnějším kamenickým prvkem byl erb v průčelí vstupní věže.

Severní fasádou též prosvítaly zbytky rýsované rustiky, která byla důsledně dotažena až ke kamenným ostěním oken patra. Pozoruhodná byla jizva po úzkém arkýři v patře a v přizemí byl patrný otisk pilířku, jenž ho podpíral. S velkou pravděpodobností šlo o arkýř prevétu, který 




Obr. 8. Stlačená křížová klenba ve třetí místnosti od východu v severním traktu přízemí, 1997.

Abb. 8. Zusammengedrücktes Kreuzgewölbe im dritten Raum von Osten im Nordtrakt des Erdgeschosses, 1997.

zlikvidovali snad při barokních úpravách. Okenní výplně byly kvalitní, patrně z 19. století, vnější při rekonstrukcích 20. století často zaměnili. Dochovala se i kvalitní kování s oválnými kličkami, u vyměněných vnějších oken byla místy nahrazena novějšími. Poměrně hodnotné a jistě i funkční byly též provlékané kované mř́iže oken v př́izemí a uchování zasluhovalo i schodiště s pískovcovými stupni, jeho dřevěné zábradlí a kamenná dlažba podest. Zvláštní z hlediska hodnoty byl uchovaný centrální kouřový sběrač východní poloviny dispozice a pozůstatky stroje hodin v podstřeší vstupní věže, kde je zajímavá i konstrukce krovu

Jelikož v roce 1998 proběhl stavebně historický průzkum zámku, je možné předložit představu o jeho počátcích a vývoji. Přirozeně ji limitují možnosti povrchového průzkumu při absenci výzkumu archeologického. S hledáním pozůstatků původního panského sídla rodu z Kněžic ve hmotě objektu je nutné se rozloučit. Ačkoliv zámek nebyl kontinuálním pokračovatelem sídla ze 13.-15. století, dodržel alespoň tradici jeho situování. Z pramenů plyne, že s existencí nejprve rezidenčního dvora v prostoru zámku, a posléze tvrze, která se z něho vyvinula, se dá počítat až v polovině 14., resp. na počátku 15. století. Iniciátorem úpravy dvora na tvrz byl patrně Bohuš z Holoubka, jenž po ztrátě hradu Holoubka sídlil na Kněžicích, a psal se po nich, a roku 1417 prodal již tvrz Janu Drhovi z Dolan. Jelikož ve hmotě zámku chybí jakýkoliv gotický relikt, měla tvrz zřejmě netrvalý charakter, a protože se dále neuvádí, již za pohnutých událostí husitských válek patrně zanikla. K obnově nebyl důvod, nebot' majitelé měli jiná a kvalitnější sídla.

Brzká obnova hospodářského dvora nepřekvapuje a u něho teprve se značným časovým odstupem páni z Valdštejna z blízké Brtnice postavili pro své občasné pobyty něco jako dependencii k již přestavěnému brtnickému sídlu. Připomíná se tehdy obvyklým termínem pro panský dům - tvrz - až při konfiskaci roku 1622, ale vznikla jistě nedlouho předtím. Podle literatury se tak stalo už v 80. letech 16. století (Hosák-Zemek 1981, 122), což však není možné ani podle údajů dochovaných urbářů a pramenů, ani ze slohových důvodů. Stavebníkem nebyl Hynek († 1596), tím méně jeho vdova Kateřina († 1600), ale až Zdeněk z Valdštejna. 
K jeho založení patří celý blok zámku se vstupní věží do výšky podstřeší a s východní věžicí v přízemí otevřenou do tří stran arkádou na zděných okosených pilíríich. Výtečně se dochovalo celé přízemí zámku z velké části zaklenuté, původní snad byl i trámový strop východních prostorů. Ovšem klenbu mělo př́izemí navazující rizality. Nejvíce se proměnila vstupní schodištová hala, v jejíž střední partii lze identifikovat relikty zdí renesančního schodiště. Plochostropé patro si uchovalo poněkud zamlžené dělení prostorů, ale zato téměř všechna kamenná okenní ostění. Hlavní sál zabíral napříč východní díl dispozice a jako pavilon využíval prostor rizalitu. Bohužel se nedochovaly žádné další články kamenické výpravy, která podle všeho nebyla bohatá. Utváření kleneb a použití prostých ostění s lištou ukazuje na využití domácích mistrů a kameníků i pozdní dobu vzniku krátce před započetím české války v roce 1619. Asi hned na počátku své existence byl zámeček volně propojen s úřední patrovou budovou dvora, kterou rovněž do pozdně renesančního období řadí některé dochované klenby.

Další stavební proměny zámku je možné vřadit až do doby okolo třetiny 18. století. Logicky nelze vyloučit opravy, drobné úpravy a nutnou údržbu, což se ovšem slohově neprojevilo. Z historických okolností a rámcového slohového zařazení pilastrů druhého rizalitu lze soudit na pilného stavebníka a milovníka umění Antonia Rombalda hraběte Collalta (1708-1740). Časově to je také nejzazší možnost pro zřízení křrižové klenby v původně rovněž otevřeném př́izemí rizalitu, a to i při pravděpodobné snaze po jistém přizpůsobení (podseknuté patky) existujícímu opusu. Stavbou rizalitu dosáhl stavebník zvýšení členitosti a alespoň jakéhosi dojmu barokní souměrnosti nejexponovanějšího průčelí. Při té př́ležitosti byly upraveny interiéry, o čemž svědčí štuková výzdoba stropů, která také poukazuje na pozdější vznik než v době kolem roku 1700, o níž hovoří literatura. Významným zlepšením pohodlí bylo zřízení koư̌ového sběrače (druhý menší byl možná vedle schodiště na půdu), který výmluvně hovoří o využití kachlových kamen.

K opětné rozsáhlejší stavební činnosti došlo až v empiru za knížete Eduarda Collalta (1793-1833) a možná k tomu dalo impuls předpokládané využití zámku jako lazaretu za napoleonských válek. Co se týče exteriéru, hlavní změnu představuje zazdění otevřených arkád v př́izemí věžic a zapojení nových přízemí mezi obytné prostory, navíc dostala okna vstupní věže a portál vchodu typické půlkruhové záklenky. Při velké proměně vstupní haly empirové schodiště nahradilo starší, zbývající se promítly do vybavení a do otvorových prvků, které však vyměňovali ještě koncem 19. století a př́i úpravách zámku k trvalému pobytu Eduarda Mensdorfa-Pouillyho po roce 1927.

Tím je výčet zhodnocujících či uměřených akcí vyčerpán. Zásadní změny využití po roce 1945 přinesly necitlivé, ba škodlivé utilitární úpravy, které nepřihlížely k historicko-kulturním hodnotám objektu. Rozdělení východního sálu je možné připsat úpravám na školu, betonové podlahy dostaly zrrízené dílny v prŕizemí a k adaptacím znovu došlo v letech 1960-1972. Odstraněny byly zbytky parku, ale následně po stavbě kulturního domu aspoň nejnutněji upravili plochy jižně před zámkem. Rekonstrukci budovy dvora sousedící se zámkem na zdravotní středisko provedli v roce 1990, ale zámek musel na obnovu a revitalizaci ještě počkat.

Kněžický zámek je velmi pozoruhodným a dobře dochovaným př́íkladem venkovského šlechtického paláce - dependencie - určeného $\mathrm{k}$ př́ležitostným pobytům panstva sídlícího trvale $\mathrm{v}$ Brtnici, a to $\mathrm{z}$ období pozdní renesance těsně předbělohorského období. To, že se na stavbě uměleckohistoricky téměř neprojevil dobový manýrismus, plyne ze vzdálenosti center uměleckého dění a z relativní nedůležitosti stavby, nebot' jako trvalá rezidence počala paradoxně a krátce sloužit až v období první republiky. Prameny neuvádějí její původní funkci, obecná literatura ji však nazývá loveckým zámkem, což není správné (Hosák-Zemek 1981, 122; Hrady a zámky 1987, 97). Skutečný, i když pozdější lovecký zámeček stojí ve středu hvězdice lesních alejí v lesích západně od Brtnice a jmenuje se případně Aleje.

Z nemnoha analogií nejbližší představuje zámek v nedaleké Černé. Oba objekty jen zdánlivě spojuje pozdější collaltovské vlastnictví. Pro funkční spř́iznění jsou podstatné společná patrová bloková dispozice s věží v jižním průčelí, vznik na počátku 17. století (po roce 1605) a role druhého, vedlejšího sídla. Podle epigrafiky nad portálem totiž zámek v Černé vystavěl jako další 


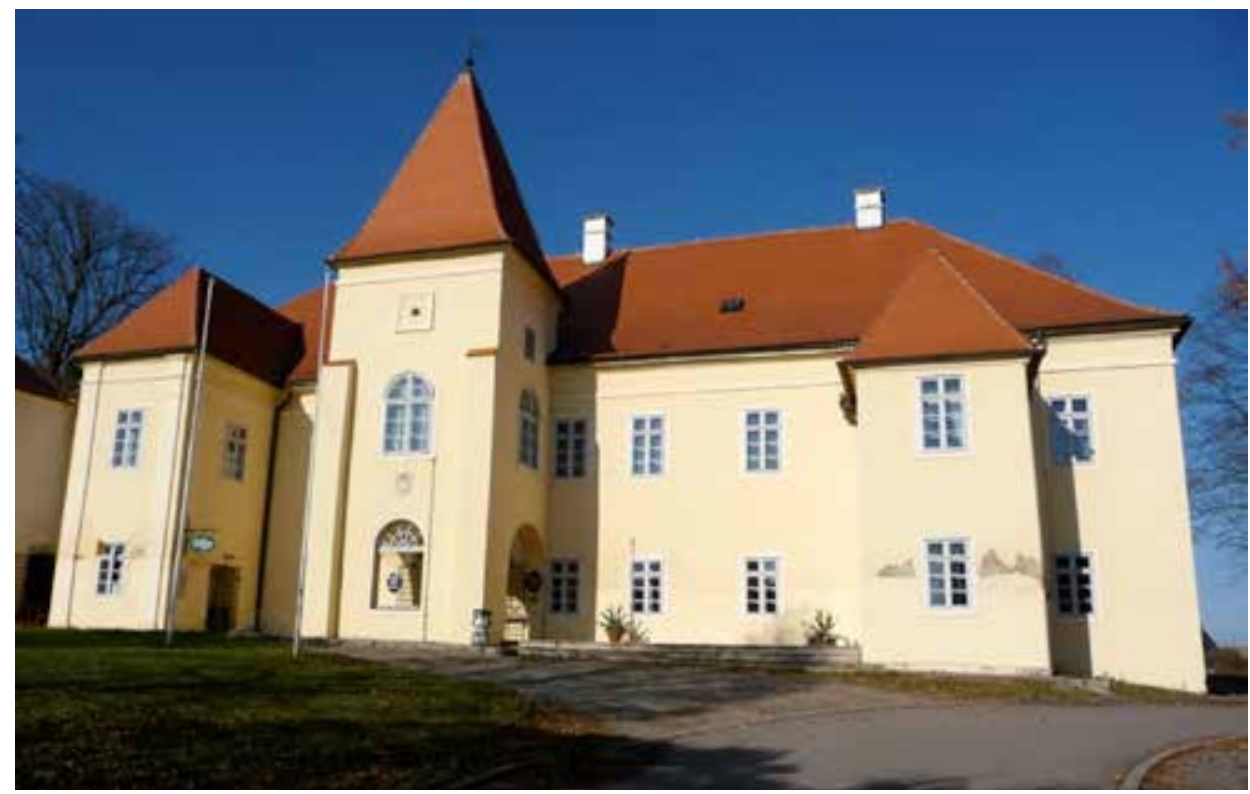

Obr. 9. Zámek od jihu po revitalizační památkové obnově, 2016.

Abb. 9. Schloss von Süden nach erfolgter Denkmalsanierung, 2016.

své sídlo Jan Rafael Chroustenský z Malovar, který jinak sídlil na (Německém) Rudolci. Přes pohnuté osudy si kněžický zámek do našich dob uchoval značnou autenticitu př́izemí, včetně kleneb a ani barokně klasicistní podstata patra nebyla narušena nevratně. Ráz a hodnota staticky neohroženého objektu samy o sobě doporučovaly obnovu a využití zámku. Již proto, že zmíněná obdoba v Černé je upravena pro provoz erotického klubu a její památková působivost na poměrně úzký okruh návštěvníků je navíc omezena jejich poněkud odlišnými zájmy.

Stavebně historický průzkum prokázal hodnoty kněžického zámku a stupeň jeho dochování. Potřebnou revitalizaci přinesla zámku nejen obnova, ale i očištění kulturně historické podstaty od znehodnocujících nánosů. Obec potřebuje též stánek nekonzumní kultury, jiný, než jakým je do jisté míry ideologicky orientovaný kulturní dům, a z hlediska sepětí života obce se zámkem je přece jen symbolické, když obnovou zámku samospráva obce pro svou činnost získala důstojné prostory. Podrobnosti o konečném produktu revitalizace autor nezná a jen doufá, že došlo k opravě starších hodnotných výplní otvorů (okna, dveře) a jejich kování. Jen škoda, že hledání předchůdce zámku, at' již archeologickými, či geofyzikálními metodami komplikuje úprava okolí a novodobá zástavba severně od zámku.

\section{Prameny a literatura}

BALCÁREK, P., 1988: Brtnice ve víru třicetileté války. In: Dějiny Brtnice a připojených obcí, 133-149. Brno.

CDB I: Codex diplomaticus et epistolaris regni Bohemiae I, 805-1197 (Friedrich, G., ed.). Pragae 1904-1907. CDB II: Codex diplomaticus et epistolaris regni Bohemiae II, 1198-1230 (Friedrich, G., ed.). Pragae 1912. CDB V/1: Codex diplomaticus et epistolaris regni Bohemiae V/1, 1253-1267 (Šebánek, J.-Dušková, S., edd.). Pragae 1974. 
CDB V/2: Codex diplomaticus et epistolaris regni Bohemiae V/2, 1267-1278 (Šebánek, J.-Dušková, S., edd.). Pragae 1981.

CDM V: Codex diplomaticus et epistolaris Moraviae V, 1294-1306 (Boczek, A.-Chytil, J., edd.). Brunnae 1850 .

CDM VII: Codex diplomaticus et epistolaris Moraviae VII, 1350-1355 (Brandl, V., ed.). Brünn 1874.

HOSÁK, L., 1938: Př́íspěvky k starému rodopisu moravskému IX, ČSPS 46, 154-155.

- 1938a: Historický místopis země Moravskoslezské I. Praha.

- 1952: Středověká kolonizace horního poříčí Jihlavy, ČSPS 60, 142-153.

HOSÁK, L.-ŠRÁMEK, R., 1970: Místní jména na Moravě a ve Slezsku I. A-L. Praha.

HOSÁK, L.-ZEMEK, M. a kol., 1981: Hrady, zámky a tvrze v Čechách, na Moravě a ve Slezsku I. Jižní Morava. Praha.

HRADY A ZÁMKY 1987: Hrady a zámky na Moravě (Heimrichová, R.-Ludvík, M., edd.). Praha.

HRUBÝ, F., 1927: Odhady konfiskovaných moravských velkostatků (1622-1623), ČMM LI, 124-129.

CHAROUZ, Z., 1984: Př́íspěvek k moravské topografii, ČMM CVII, 312-320.

KNOZ, T., 2006: Pobělohorské konfiskace. Moravský průběh, středoevropské souvislosti, obecné aspekty. Brno.

KUDĚLKA, Z., 1977-1978: Výzkum románské architektury I, SPFFBU F 21-22, 39-42.

LC II: Libri citationum et sententiarum seu Knihy půhonné a nálezové II (Brandl, V., ed.). Brunae 1873.

LC V: Libri citationum et sententiarum seu Knihy půhonné a nálezové V (Brandl, V., ed.). Brunae 1888.

MĚŘÍNSKÝ, Z., 1988: Počátky osídlení Brtnicka a nejstarší dějiny obce. In: Dějiny Brtnice a připojených obcí, 13-49. Brno.

- 2007: Hrad Rokštejn, Dějiny stavební vývoj a výsledky archeologického výzkumu 1981-2006. Brtnice - Brno.

MĚŘÍNSKÝ, Z.-PLAČEK, M., 1989: K podobě nejstarší kamenné fáze hradu Bítova (okr. Znojmo), CB 1, $229-244$.

MZA Brno, fond G 10 Nová sbírka rukopisů; fond G 169 Rodinný archiv Collaltů; fond G 2 Nová sbírka.

NEKUDA, V.-UNGER, J., 1981: Hrádky a tvrze na Moravě. Brno.

PAPAJÍK, D., 2005: Páni ze Sovince. Dějiny rodu moravských sudích. Praha.

- 2007: Páni z Holštejna. Významný, ale zapomenutý panský rod. České Budějovice.

PÁTEK, A. J., 1901: Jihlavský okres. Vlastivěda moravská. Brno.

PILNÁČEK, J., 1930: Staromoravští rodové. Vídeň.

PLAČEK, M., 2015: K historii Boleradic a jejich hradu. In: Boleradický hrad (Unger, J., ed.), 55-64. Brno.

RICHTER, V., 1953: K nejstarším dějinám Třeště, ČSPS 61, 7-37.

SAMEK, B., 1999: Umělecké památky Moravy a Slezska II. J/N. Praha.

SEDLÁČEK, A., 1893: Rozletité kapitoly ze starého místopisu a dějin rodů, ČMM XVII, 287-300.

VEČĚ̌A, J.-ONDRÁČEK, A.-PEJCHAL, O., 1994: Kněžice. Díl I. Domovopis. Kněžice.

VOHRYZEK, S., 2011: Hrut z Rokštejna, moravský podkomoř́í?, AVV 2, 46-50.

- 2012: Stř́ižovci v 2. polovině 14. století, AVV 3, 67-74.

- 2013: Rod pánů z Hrádku, Říše, Starče a Holoubka, JM 49, sv. 52, 131-155.

ZAORALOVÁ, M., 1988: Od husitství do Bílé hory. Období druhého nevolnictví 1648-1740. In: Dějiny Brtnice a připojených obcí, 101-132, 151-177. Brno.

ZAORALOVÁ, M.-JANÁK, J., 1988: Přechod od feudalismu ke kapitalismu. In: Dějiny Brtnice a připojených obcí, 179-212. Brno.

ZDB I-XIV: Die Landtafel des Markgrafthumes Mähren. Brünner Cuda (von Chlumecky, P. R.- Chytil, J.Demuth, C.--von Wolfskron, A. R., edd.). Brünn 1856.

ZDB XV-XXVIII: Moravské zemské desky 1480-1566. II. Kraj brněnský (Kalina, T., ed.). Praha 1950.

ZDB XXIX-XXXIX: Moravské zemské desky 1567-1641. III. Kraj Brněnský (Rohlík, M., ed.). Praha 1957.

\section{Zusammenfassung}

\section{Kněžice/Knieschitz - zunächst ein Herrenhof - schließlich eine Dependance der Spät- renaissance}

Knieschitz findet erstmals im Jahre 1222 Erwähnung, und zwar im Adelsprädikat eines Dietrich. Zusammen mit seinem Sohn Hrut gehörte er dem Adelsgeschlecht der Hrut an, und Knieschitz haben sie wohl von ihrem Dienstherrn als Lohn für die Ausübung von Ämtern in den 
Regionen von Bítov und Znaim erworben (Dietrich 1225-1232, Hrut 1232-1259). Dem Namen nach war das Dorf noch zur Fürstenzeit entstanden. Dietrich war im Jahr 1289 der letzte Hrut in Knieschitz, bekannt sind aber auch andere Zweige, gar nicht zu reden erst von den Herren von Holstein und von Sovinec. Das verwandte Geschlecht der Hrut aus dem Jahr 1289, welche die Burg Ruckstein (Rokštejn) gegründet hatten, gehörte jedoch nicht zu ihnen. Bis zur Mitte des 13. Jahrhunderts konnte der Sitz der Hrut in Knieschitz nur ein Residenzhof sein. Anfang des 15. Jahrhunderts erlangte er die Form einer Feste, die im Süden der Gemeinde stand und nicht an der romanischen St. Jakobskirche, wo Mitte des 13. Jahrhundert bereits die Probstei der Seelauer Kanonie - eine bessere Pfarrei - entstanden war.

Ein im Jahr 1351 nach dem Dorf Knieschitz erwähnte Hrut von Knieschitz stammte bereits aus dem Geschlecht der Herren von Beneschau und verkaufte die Grundherrschaft an Bohuslaw von Stařič und Holubek (Holaubek, Taubenstein). Diese erbte dessen Sohn Niklas Rulant, der im Jahr 1376 einen Hof errichtete und diesen im Jahr 1390 seinem Bruder Bohuslaw überschrieb. Von diesem wird im Jahr 1406 der Hof, ein Fischteich und eine sich dabei befindende Mühle erneut erwähnt. Er hat ausdrücklich auf dem Hof gewohnt und sich nach Kněžice genannt, und im Jahre 1417 ließ er das Gut bereits mit Feste auf Johann von Drha von Dolan intabulieren. Die bescheidene Feste war wohl bis Mitte des 15. Jahrhunderts während des Krieges untergegangen, der Hof wurde wieder aufgebaut. Hundert Jahre später löste Seelau seine Probstei auf, die von den Waldsteins ebenfalls Pirnitz angegliedert wurde. Im Jahr 1600 erbte Zdeněk von Waldstein die Grundherrschaft, der wegen seiner Teilnahme an der Rebellion im Jahr 1623 im Gefängnis zu Tode kam. Die beschlagnahmte Grundherrschaft erwarb Rombald de Collalto et San Salvatore auch mit der Feste in Knieschitz. Aus den Quellen geht hervor, dass sie zwischen den Jahren 1590-1619 errichtet worden war.

Die Collalti haben das von den Schweden beschädigte Schloss in Pirnitz und mit diesem auch die Burg Sadek und das kleine Knieschitzer Schloss wieder aufgebaut, das im ersten Drittel des 18. Jahrhunderts barock umgebaut wurde. Die Folgen der napoleonischen Kriege wurden offenbar von (1793-1833) durch eine Umgestaltung des Schlosses im Empire-Stil ausgemerzt. Nach dem Jahr 1920 fiel das Schloss dem Restbesitz von Oktavian Collalto zu. Dessen Schwager, Graf Eduard Mensdorf-Pouilly, hat es dann im ersten Drittel des 20. Jahrhundert zum Wohnen hergerichtet. Nach dem Ende des Zweiten Weltkrieges wurde das Schloss geplündert und verstaatlicht. Die durch mannigfaltige Nutzung des Schlosses in der Nachkriegszeit verursachten Schäden wurden von der seit 2003 erfolgenden Sanierung behoben.

Knieschitz zieht sich über die Westterrasse des Flusstals der Pirnitz und endete an der Einmündung eines Nebenflusses. Auf einem Plateau dahinter befand sich der Dominikalbezirk mit Schloss, Hof, Park und an dessen östlichem Fuß ein Fischteich mit der sog. Herrenmühle. Das kleine rechteckige und einstöckige Schloss hat in der Südfassade einen, im Erdgeschoss nach den Seiten hin offenen Eingangsturm und zwei Risalite. Das überwiegend eingewölbte Erdgeschoss besteht aus einem länglichen Doppeltrakt, von denen der nördliche Trakt sieben und der südlich nur drei Räume enthielt, der größte war das Eingangsvestibül mit (auch renaissancezeitlichem) Treppenhaus. Die Anlage des mit flachen Decken ausgestatteten ersten Stocks ist etwas anders. Die Mauern des Schlosses sind aus Stein und gemischt, die jüngeren aus Ziegelsteinen, die Fassadengliederung ist grob. An Steinmetzarbeiten finden sich lediglich einfache, mit Leisten versehene Fensterlaibungen.

Bei den Gewölben handelt es sich um flache Kreuzgewölbe mit aufeinanderstoßenden Gewölbekappen. Die vorgezogenen Kanten gehören zur ausklingenden Renaissance, ein Teil der Flachdecken war mit Stuckrahmen und Spiegeln versehen. Von den Balkendachstühlen ist der Dachstuhl des Eingangsturms aus der Barockzeit wertvoll. Die Fassaden wurden mit Ausnahme der Südfassade grob abgehandelt und sind nur minimal gegliedert, vor der Restaurierung hat stellenweise eine sich hell abzeichnende Rustika durchgeschienen. Von hohem Wert war der barocke Rauchfang in der Ostpartie. Die im Jahr 1998 durchgeführte bauhistorische Untersuchung lieferte eine Vorstellung von der Entwicklung des kleinen Schlosses, jedoch sind uns die Überreste des Objektes aus dem 13.-15. Jahrhundert unbekannt, da sie in seiner Baumasse 
nicht enthalten sind. Der Hof, an dem sich eine Feste entwickelte, existierte Mitte des 14. Jahrhunderts. Neben dem Hof errichtete Zdeněk von Waldstein eine Dependance der umgebauten Pirnitzer Residenz, die im Jahr 1622 als Feste erwähnt wird. Erhalten geblieben ist das ganze Erdgeschoss und die Fensterlaibungen im ersten Stock. Sehr verändert hat sich die Eingangshalle. Von Anfang an war das kleine Schloss mit dem einstöckigen Amtsgebäude des Hofs frei verbunden. Der Umbau im ersten Drittel des 18. Jahrhunderts äußerte sich durch einen Westresalit und durch die Verzierung der Decken des ersten Stockwerks.

Unter Eduard Collalto (1793-1833) kam es zu einer erneuten, im Empire-Stil erfolgten Bautätigkeit, damals wurden die offenen Arkaden im Erdgeschoss der kleinen Türme zugemauert, darüberhinaus erhielt der Eingangsturm Fenster. In der Eingangshalle wurde der ältere Treppenaufgang durch einen neuen ersetzt, weitere Umbauten erfolgten Ende des 19. Jahrhunderts und nach dem Jahr 1927. Die nach dem Jahr 1945 verursachten Schäden wurden teilweise durch die in jüngster Zeit erfolgte Denkmalsanierung beseitigt.

Das Knieschitzer Schloss ist ein bemerkenswertes adeliges Land-Palais der Spätrenaissance, in dem sich die Herrschaft gelegentlich aufhielt. Von der allgemeinen Literatur wird es fälschlicherweise als Jagdschloss bezeichnet, jedoch steht das spätere Jagdschloss in den westlich von Brtnice liegenden Wäldern und heißte Aleje. Von den wenigen Analogien steht ein Objekt im nahegelegenen Černá der Dependance am nächsten. Außer der funktionellen Verwandtschaft haben sie die einstöckige Blockanlage mit einem Turm in der Südfassade, die Entstehung nach dem Jahr 1605 und ihre Rolle als Nebenresidenz gemeinsam.

doc. Ing. PhDr. Miroslav Plaček, Ústav archeologie a muzeologie Filozofické fakulty Masarykovy univerzity, Arna Nováka 1, 60200 Brno, Česká republika, mplaczek@seznam.cz 
